\title{
EVOLUTION AND EFFECTIVENESS OF COLORMETRIC APPROACH FOR INVESTIGATION OF CEFTRIAXONE MEDICINE AS IN PURE FORM AND IN FORMULATION VIALS
}

\author{
Mohauman Mohammad Majeed AL-Rufaie \\ Chemistry Department, College of Science, Kufa University \\ Iraq
}

Corresponding author, email: muhaimin.alrufaie@uokufa.edu.iq

\begin{abstract}
A third-generation cephalosporin antibiotic was aceftriaxone medicine. Similar another $\left(3^{\text {rd }}\right.$ generation cephalosporins), it has wide broad spectrum effectiveness versus gram positive as well as gram negative bacteria. Diverse approachs for analyses of the studied medicine are obtainable but are costly additionally time consumption. Therefor we have sophisticated developed novel, easy, simple as well as accurate colormetric approach for investigation of ceftriaxone medicine as pure form as well as in formulation vials by depending on a specific color-generated reaction. This reaction involves the Schiff 's base formation reaction between ceftriaxone drug with alcoholic 4-di ethyl amino benzaldehyde (DEAB) reagent to produce a new ligand that reacts with cobalt (II) ion with heating to $\left(50^{\circ} \mathrm{C}\right)$ in acidic media to form green colored complex exhibiting $\lambda$ max at $496 \mathrm{~nm}$. The medicine conformed with the Beer's law with the linearity was observed between (2 -52) $\mu \mathrm{g} / \mathrm{ml}$ additionally that correlation coefficient was 0.9992 .The analyses outcomes were supported with LOD, LOQ, accuracy, recovery studies, ruggedness as well as precision. The approach was establish to be robust as well as economical.
\end{abstract}

Keywords: Ceftriaxone, evolution and effectiveness, colormetric approach

\section{INTRODUCTION}

Antibacterial action of ceftriaxone medicine CFT is produced through the suppression of mucopeptide formation in the cell wall of bacterial as well as by joining with to the penicillin-joining proteins (PBPs) with one or more position which in benignity prohibits the end transpeptidation stride for peptidoglycan composition in the cell walls of bacterial, thus obstruction fot the biosynthesis of cell wall for bacterial. This leads to subsequent cell death by analysis due to on-going activity of cell wall autolytic enzymes continues while cell-wall assembly is arrested ceftriaxone sodium is well absorbed intramuscularly and possesses a complete bioavailability after intramuscular and intravenous

J. Islamic Pharm., an open access journal ISSN : 2527-6123 
administration. Urinary excretion is the major elimination pathway for ceftriaxone sodium. As such, 33-67\% of dose is excreted in urine as unchanged drug and the remaining fraction is eliminated in faces through bile.Biliary elimination is significant for Ceftriaxone [1 and 2].

CFT is overwhelmingly utilized (in integration with macrolide as well as aminoglycoside antibiotics). The remediation of combination- obtained acquired pneumonia. It is furthermore a medicine of cucumber for the remediation of bacterial meningitis.In paediatrics, it is ordinarily utilized in pyretic toddler. It has furthermore been utilized in the remediation of leptospirosis,gonorrhea as well as lyme disease. It is likewise utilized as a habit preventative antibiotic for the patients incuring orthopedic operation [3]. Ceftriaxone (M.wt=662) chemically defined as, (IUPAC name) 6R,7R,Z)-7-(2-(2-amino thiazol-4-yl)-2(methoxy imino) acetamido)-3-((6-hydroxy-2-methyl -5-oxo - 2,5- dihydro -1,2,4-triazine-3ylthio)methyl)-8-oxo-5-thia-1-aza-bicyclo[4.2.0]oct-2-ene-2-carboxylic acid 3.1/2 hydrate; with the chemical formulation $\mathrm{C}_{18} \mathrm{H}_{16} \mathrm{~N}_{8} \mathrm{Na}_{2} \mathrm{O}_{7} \mathrm{~S}_{3}, 3.1 / 2 \mathrm{H}_{2} \mathrm{O}$, and a calculated molecular weight of 661.59 , is a third generation cephalosporin antibiotic. It has the following structural formula. Figure (1) [1,2, and 4].

Sundry analytical approaches have been introduced for the analyses of CFT, instituted based on thin layer chromatographic [5-7] derivative spectrophotometric [8], spectrophotometric [9-15], flour metric [16,17], FIA [18], high performance liquid chromatographic [19,20], ion exchange chromatographic [21], ion selective electrodes [22], polarographic and voltammetry techniques [23 and 24] and ion pair liquid chromatographic [25]. For colormetric analyses, the investigation is achieved with utilizing convenient reagent DEAB is putted for the foremost time as a derivate reagent for colormetric investigation of CFT in pure form as well as in formulation vials. The objective from the existing paper was to explain the interaction between reagent DEAB as well as CFT to produce a new ligand that complexing with cobalt chloride solution with the existence of acidic media iodate to form new color complex that utiizing for the spectrophotometric investigation of Ceftriaxone drug.

\section{MATERIAL AND METHOD}

\section{Materials and reagents}

Reagents,instrumentation as well as chemicals: devices exercised were a double-beam applied by digital enrollmentUV-Visible spectrometer (Japan), analytical balance (Sartorius BL 210S), Heating-cooling water bath (Haake, $\mathrm{Fe}_{3}$ ) The chemicals which were used in the 
procedure with highly degree of purity and did not need to purification, all reagents in the research was given from (BDH reagent laboratory, Chemicals Ltd), ceftriaxone pure drug 500 ppm solution obtained by dissolution $0.05 \mathrm{~g}$ of CFT in a volumetric flask $100 \mathrm{ml}$ with deionized water.alcoholic (4- di ethyl amino benzaldehyde) DEAB reagent $2.0 \%$ w/vsolution obtained by dissolution $2 \mathrm{~g}$ of DEAB reagent in $100 \mathrm{ml}$ by ethanol absolute by the volumetric flask. Hydrochloric acid $1 \mathrm{M}$ solution obtained by adding $(4 \mathrm{ml})$ form concentrated Hydrochloric acid in $100 \mathrm{ml}$ volumetric flask , mixed well and completed the volume by deionized water.cobalt chloride $\left(\mathrm{CoCl}_{2} \cdot 6 \mathrm{H}_{2} \mathrm{O}\right) 0.02 \mathrm{M}$ solution given by dissolving $0.471 \mathrm{~g}$ of fresh material in the $100 \mathrm{ml}$ deionized water.

\section{Assay procedure for ceftriaxone sodium in formulation vials samples}

A number of vials containing CFT as ingredient active were analyzed. These are summarized in Table 1.

\section{Dry Injection Procedure}

The $0.05 \mathrm{~g}$ powder of every type of vials which was containing CFT as antibiotic was taken into flasks volumetric $100 \mathrm{ml}$ as well as weakened up to the imprint with water solvent. At that point we computed the concentration by using the calibration graph [4].

\section{Common procedure}

Aliquots of $(0.2 \mathrm{ml}-4.0 \mathrm{ml})$ CFT token into a collection of $25 \mathrm{ml}$ volumetric flasks.To everyone, alcoholic solution for DEAB reagent $2.0 \mathrm{ml}$ was used additionally $1.5 \mathrm{ml}$ cobalt chloride $0.02 \mathrm{M}$ was added and acidic the solution by utilizing $0.25 \mathrm{ml}$ for $0.5 \mathrm{M} \mathrm{HCl}$ solution. The product solution was warming at $50^{\circ} \mathrm{C}$ for 40 minutes in the bath of water to form the color solution. the volume was brought up to tick by water as well as the colored complex absorbance was appointed at $496 \mathrm{~nm}$ as $(\lambda \max )$ contra the blank solution. The colored classes as steady for extra time high than 3 hour. The measure of CFT concetration current in the samples was checked from calibration diagram. The colour was constituted to be constant for up one 2 days [13].

\section{RESULT AND DISCUSSION}

\section{Wavelength chosen of absorption spectra}

For the measurement of the amount of drug by the studied approach, the maximum wavelength for the absorbance performs an paramount function. It is indispensable to adopt the wavelength whereover the DEAB agents as well as cobalt ion point out lower absorbance 
additionally the analyte derivative appears ultimate absorbance account in acidic media. The absorbance value of the result concentration $20 \mu \mathrm{g} / \mathrm{ml}$ of CFT) and (DEAB) reagent,cobalt ion derivative was registered at diverse wavelengths between $300-600 \mathrm{~nm}$ after warming to $50^{\circ} \mathrm{C}$ for 40 minutes using acidic media. It is obvious that the ultimate absorbance happened in visible district at $496 \mathrm{~nm}$ contra blank solution as well as was elected as exemplary [26]. Figure (2).

\section{DEAB concentration influence}

The influences of appending for the solutions with diverse DEAB concentration on the absorbance of $1 \mathrm{ml}$ of $500 \mu \mathrm{g} / \mathrm{ml}$ CFT was checked by Table (2). The DEAB concentration was diversified by the range from $(1-6 \mathrm{ml})$ of $2.0 \% \mathrm{w} / \mathrm{v}$ of DEAB reagent in ethyl alcohol with a spacing of $1 \mathrm{ml}$ A maximum absorbance for the product solution was observed with addition of $2 \mathrm{ml}$ from $(2 \% \mathrm{w} / \mathrm{v})$ DEAB reagent solution. That was selected in the next tests [27].

\section{Cobalt chloride concentration influence}

The influences of appending for the solutions with diverse cobalt chloride concentration on the absorbance of $1 \mathrm{ml}$ of $500 \mu \mathrm{g} / \mathrm{ml}$ CFT was checked by Figure (3). The cobalt chloride concentration was diversified by the range from (1-5ml) of $0.02 \mathrm{M}$ in deionized water with a spacing of $(0.5 \mathrm{ml})$. The maximum absorbance for the product solution was appeared with addendum of $1.5 \mathrm{ml}$ from $0.02 \mathrm{M}$ of Cobalt chloride solution. That was selected in the next tests [28].

\section{Selection of media}

It was found that the presence of acidic media led to increase the intensity of absorbance for the color product more than basic and natural media, therefore some acids such as $\mathrm{CH}_{3} \mathrm{COOH}, \mathrm{HCl}, \mathrm{HNO}_{3}$ as well as $\mathrm{H}_{2} \mathrm{SO}_{4}$ are examined at $(1 \mathrm{M})$ as concentration it was found that all these acids gave the absorbance of colour product, so $\mathrm{HCl}$ was the best acid that gives the highest absorption which selected in the following experiments. Which was found that $(0.25 \mathrm{ml})$ of this acid give high sensitivity which selected in subsequent experiments [27].

\section{Order of mixing for the reagents influence}

The influence of the order of mixing for the reagents through complexion operation has paramount function in reliabilityof results as well as augmentation of the absorbance. In the sitting project, it was appeared that the addendum $1 \mathrm{ml}$ of $500 \mu \mathrm{g} / \mathrm{ml}$ CFT (D) solution 
followed by $2 \mathrm{ml}$ of DEAB $(\mathrm{R})$ reagent solution .after that Taking $1.5 \mathrm{mlcobalt}$ chloride $(\mathrm{M})$ added, at least the acidic solution $1 \mathrm{M} \mathrm{HCl}$ (A) with $0.25 \mathrm{ml}$ was adding to form the acidic media, the maximum absorbance value was observed after that making the dilution. This order are used in the next tests [26]. Table (3).

\section{Optimization of heating time and temperature:}

To realize the ultimate absorbance amount for an CFT by the figuration of stationary stable color complex, the election of the best temperature as well as is fundamental.The temperature influence on the figuration of derivative was limited at $496 \mathrm{~nm}$ by the range from $\left(0-80^{\circ} \mathrm{C}\right)$ by heating in water bath with an interval of $\left(5^{\circ} \mathrm{C}\right)$. The heating time effect on the figuration of derivative was calculated at $496 \mathrm{~nm}$ from( 0 - 80min) also with a spacing of (5 min). A maximum absorbance was appeared after warming for $(40$ minute $)$ at $\left(50^{\circ} \mathrm{C}\right)$ additionally was believed as ideal. that was used in the following tests [28]. Table (4).

\section{Solvents infuence}

The different solvents influence like ethanol, 2-propanol, methanol, 1-butanol, acetone, chloroform, dimethyl sulphoxide, benzene, teri butyl alcohol, nitrobenzene, formic acid, dimethyl formamide, di ethyl ether and carbon tetrachloride on the absorbance was studied. Table (4) shows the effect solvent, water was the best solvent, which giving very high intensity of maximum absorbance water is achieved to be a decent solvent from the point perspective of economy as well as sensitivity. Water utilized for the dilution to the mark of (25 $\mathrm{ml}$ conical flask). After heating the result solution for $(40 \mathrm{~min})$ at $\left(50^{\circ} \mathrm{C}\right)[26]$.

\section{Beer's law calibration diagram}

The variation in the CFT concentration influence on the color produc absorbance was checked. After applying the perfect circumstances was showing by the procedure, a linear calibration diagram was acquired which conformed with the Beer's law through the range of concentration $\left(2-52 \mu \mathrm{g} \cdot \mathrm{ml}^{-1}\right)$ of CFT antibiotic with coefficient of investegation $\mathrm{r}^{2}(0.9992)$ figure (4).

The Sandell's sensitivity was observed $\left(4.8 \times 10^{-5} \mathrm{~g} . \mathrm{cm}^{-2}\right)$. The highly molar absorptivity for the color product was founding $2.1184 \times 10^{4} \mathrm{~L} . \mathrm{mol}^{-1} \cdot \mathrm{cm}^{-1}$. (LOD) limit of detection as well as (LOQ) limit of quantitation were checked by utilizing the equation LOD $=3 \times \mathrm{s} / \mathrm{S}$ additionally the equation $\mathrm{LOQ}=10 \times \mathrm{s} / \mathrm{S}$, where $\mathrm{s}$ is standard deviation for the intercept, the strength line slope was S. 


\section{Effectiveness}

\section{Accuracy}

To appreciate the accuracy for of the suggestted approach, recovery considerations were preformed by three various scales i.e. $\left(4,20\right.$ and 40) $\mu \mathrm{g}$. $\mathrm{ml}^{-1}$.To the pre-tested sample solution a recognized quantity standard medicine solution was adding added at three various scales, the absorbance was registered.The \% recovery was then recorded by the equation \% Recovery $=$ [(A-B) / C ] x 100. Where $\mathrm{A}$ is overall total amount of medicine assess ; $\mathrm{B}$ is the medicine amount establish on pre tested footing; $\mathrm{C}$ is the pure medicine amount added to formulation vials [27].

\section{Precision}

The approach precision is checked as during the day as well as between the days. These precisions was calculated by analyzing the identical concentration for the solutions every day for 3 days. In medium precision project, \% R.S.D. measurements were not highly than $2.0 \%$ in every one the statuses [28]. Table (6).

\section{Stoichiometric proportion investegation}

Utilizing the ideal situations, the new ligand absorbance was measuring the various concentration medicine with DEAB were installed to alter with the stoichiometric of proportion the CFT medicine as well as DEAB by utilizing mole ratio method and Job's method. The 1:1 was the mole ratio that lead to obtain the strongly absorbance measure for the new ligand, additionally for this reason that was chosen as the stoichiometric proportion for the next investegations. The stoichiometric proportion between new ligand CFT : DEAB and Co (II) of investigated macrolides in water solvent were employed to determine by moleratio and Job's method of continuous variation as follows. Confirms that the ratio of product complex new ligand CFT : DEAB : Co(II) is equal to 1:1. The products formed was water soluble. A reactions mechanism based on the above reactions is shown in schemes figure(5) [26]. The stability constant for the product compounds was figured by looking and measuring the absorbance of a solutions which including stoichiometric measure of medicine with DEAB with the perfect quantity $1 \mathrm{ml}$ of $2 \times 10^{-3} \mathrm{M}$ from medicines, and DEAB solution with other solution for cobalt ion containing a five-fold excess from the starting concentration. The average for calculated stability constant for the colour results in water under the characterized experimental circumstances was $2.41 \times 10^{6} 1^{2} \cdot \mathrm{mol}^{-1}$. The interaction may happened as obtained by the next Schemes [27-29] figure (6). 


\section{Interference study}

Under the optimized experimental conditions, the effects of additives associated with CF $\mathrm{T}$ medicine in its formulations were investigated using the developed method. The results obtained are indicated in Table. 7) and the resultsare indicating that the method is not suffering anyinterference from common exci pients and other substances added to vials preparations. the method was applied by. $1 \mathrm{ml}$ of 500ppm CFT and $1 \mathrm{ml}$ of each excipients with concentration $5000 \mathrm{ppm}$ was connected for the study of interferences after that dilution to the sign of volumetric flask $25 \mathrm{ml}$.A grade of impedance was believed to make the procedure more satisfactory if the mistake was not more than $\pm 2 \%$ in respect to the normal No obstructions were seen on the investigation of drugs within a sight of the studied excipients [30]. (Three determinations Average).

\section{Application}

The was exercised to assess of CFT in different formulation vials(Table 8), a present approach was applying for the assay of five samples and pure form for CFT medicine (vials) and comparison with the British pharmacopoeia method (Table. 8). The results shown give a reproducible and accurate result. The validation of the present suggestted approach was confirmed by applying official approach that were gotten from (2009) British [4].

The outcomes were as well matched statistically with variance ratio F-test additionally student t-test with those acquired by British pharmacopeia at $95 \%$ confidence scale with five degrees for freedom, as witnessed in (Table. 9). The result appeared that the F-test as well as t- test were minimal than the impractical account $(F=5.05, t=2.29)$. The values were for proposed method $(F=1.66, t=0.89)$ as well as the values for of the official method were $(F=1.66, t=1.09)$ marking that there was no considerable variance between the suggestted approach as well as official approach.

\section{CONCLUSION}

The suggestted approach was emphasized with a thematic of improving sentient, unpretentious as well as authoritative analytical approach hassling UV-Visible colometric approach for investegation of ceftriaxone as pure material as well as formulation vials. The approach has appropriatly perfect precision, accuracy as well as allowed as a less cost efficient effective than another approaches. The advanced approach may averted the infuence of interferences from connected substances which may soak up in the UV district. The 
analytical approach is sentient, unpretentious, specific as well as fast. Moreover it can be suitable utilized for the monotone analyses additionally the quality monitoring of ceftriaxone in formulation vials.

\section{REFERENCES}

[1] Indian Pharmacopoeia 1996 (Addendum 2002). (Govt. of India, Ministry of Health and Family Welfare, Controller of Publications, Delhi,2002,77.

[2] N. J. Montvale, Physician's Desk Reference, (Medical Economics Company Inc Montvale,2003,56.

[3] A. Mazza: Ceftriaxone as short-term antibiotic prophylaxis in orthopedic surgery: a cost-benefit analysis involving 808 patients , J Chemother.,2000, 3, 29-33.

[4] The British Pharmacopoeia, Her Majesty's Stationary Office, London, 2009, 1169,8255.

[5] S. Eric, D. Agbaba, K. Karljikovic-Rajic, D. Zivanov Stakic and S. Vladimirov: HPTLC determination of ceftriaxone, cefixime and cefotaxime in dosage forms, $J$. Pharm. Biomed. Anal., 1998,18 (4-5), 893- 899.

[6] S. A. Nabi, E. Laiq and A. Islam: Selective Separation and Determination of Cephalosporins by TLC on Stannic Oxide Layers , Acta Chromatogr.2000,14, 92-101.

[7] T. Tomasz: Two-dimensional thin-layer chromatography of eight cephalosporins on silica gel layers ,JPC-Modern TLC.,2004,17 (1) ,46-50.

[8] B. Morelli: Simultaneous determination of ceftriaxone and streptomycin in mixture by 'ratio-spectra' 2nd derivative and 'zero-crossing'3rd derivative spectrophotometry, Talanta., 1994,41(5), 673-683.

[9] S. Alaa, Amin and H.R. Gamal: Spectrophotometric determination of certain cephalosporins in pure form and in pharmaceutical formulations, Spectrochim. Acta Part A: Molec. Biomolec. Spect.,2004,60 (12), 2831- 2835.

[10] Y. N. Ni and C.X. Ge:,Simultaneous spectrophotometric determination of certain betalactam antibiotics in rabbit serum using multivariate calibration methods, Guang $\mathrm{Pu}$ Xue Yu Guang Pu Fen Xi.,2007,27(2), 355-362.

[11] D. G. Sankar, B. A. Kumar, N. Sujatha and P. V. M. Latha: Development And Validation of UV-Spectrophotometric Methods For Estimation of Ceftriaxone In Bulk And Tablet Dosage Form, Acta Cien. Ind. Chem.,2006, 32 (2) ,147-153.

[12] B. Franciszek and S. Barbara: Spectrophotometric Determination of Cephalosporins with Leuco Crystal Violet, Chem. Anal. (Warsaw).,2003,48,145-149.

[13] K. R. Patel, V. D. Patel, K. P. Patel and V. G. Patel: Development and Validation of Spectrophotometric Method for Determination of Ceftriaxone Sodium in Pharmaceutical Dosage Forms, Der Pharma Chemica,2010,2(5),255-259.

[14] K. S. Lakshmi, K. Ilango, M. N. Nithya, S. Balaji, V.W.D. Kibe and A.V.S. Kumar:A new spectrophotometric method has been developed for the determination of the potent antibiotic ceftriaxone sodium, A. J. Chem.,2007,19 (4), 2517- 2522.

[15] S. A. Patel, N. M. Patel and M. M. Patel: Spectrophotometric estimation of cefotaxime and ceftriaxone in pharmaceutical dosage forms, I. J. Pharm. Scien.,2006,68 (1),101103.

[16] R. E. Salwa, A. S. Gamal, A. M. Fardous and H. R. Azza: Analysis of cephalosporin antibiotics, J. Pharm. Biomed. Anal.,2007, 45 (1),1-19. 
[17] L.I. Bebawy, K. El-Kelani and L. A. Fattah: Fluorimetric determination of some antibiotics in raw material and dosage forms through ternary complex formation with terbium $\left(\mathrm{Tb}^{3+}\right)$, J. Pharm. Biomed. Anal.,2003,32(6),1219-1225.

[18] H.Yao, Y. Tang, Y. Li, and Y. Sun: Flow injection chemiluminescence determination of cephalosporin antibiotics by their enhancing effects on luminal-potassium periodate system, Anal. Lett.,2003,36 (14),2975-2983.

[19] M.E. Abdel-Hamid: FSQ spectrophotometric and HPLC analysis of some cephalosporins in the presence of their alkali induced degradation products, $I l$ Farmaco,1998;53 (2),132-138.

[20] L. D. Antonio, M. Antonio and O. Regina: $\mathrm{VO}^{2+}$ and $\mathrm{Cu}^{2+}$ Interactions with Ceftriaxone and Ceftizoxime. HPLC Kinetic Studies, J. Braz. Chem. Soci.,2002, 13 (1),95-100.

[21] V.V. Khasanov, E. G. Sokolovich and K. A. Dychko: Determination of ceftriaxone in blood and tissues using ion-exchange chromatography, Pharm.Chem.,2006,40(2)109111.

[22] D. J. Nickolai ,C. J. Lammel , B. A. Byford , J. H. Morris , E. B. Kaplan ,W. K. Hadley and G F Brooks: Effects of storage temperature and $\mathrm{pH}$ on the stability of eleven betalactam antibiotics in MIC trays, J. Clin. Microbiol., 1985,21(3),366-370.

[23] L. N. C. Rodrigues, M. B. V. Zanoni, and A. G. Fogg: Indirect polarographic and cathodic-stripping voltammetric determination of cefaclor as an alkaline degradation product, J. Pharm. Biomed. Anal.,1999, 21 (3), 497-505.

[24] V. S. Ferreira, M.V.B. Zanoni, and A.G. Fogg: Cathodic stripping voltammetric determination of ceftazidime with reactive accumulation at a poly-L-lysine modified hanging mercury drop electrode, Anal. Chim. Acta,1999, 384 (2), 159-166.

[25] K. Kelani, L. I. Bebawy, and L. Abdel-Fattah: Stability-indicating spectrophotometric and densitometric methods for determination of some cephalosporins, J.AOAC Int., 1998, 81 (2), 386-393.

[26] M. M. Al-Rufaie, A.N.Al-Sharefy, K.H.Kathem: New spectrophotometric method for the determination chlorpromazine hydrochloride in pharmaceutical preparations by using oxidative coupling reaction. Inter. J. of Uni. Pharmacy and Bio Sciences, 2013,2(4), 184-189.

[27] F. M. A. Rind, M. G. H. Laghari, A. H. Memon, U.R. Mughal, F. Almani, N. Memon, M. Y. Khuhawar, and M. L. Maheshwari: Spectrophotometric Determination of Ceftriaxone Using 4-Dimethylaminobenzaldehyde, Pak.J.Anal. Environ. Chem.,2008,9(2),42-48.

[28] M. M. Al-Rufaie: Modern kinetic spectrophotometric procedure for estimation of furosemide drug as bulk form and in pharmaceuticals preparations, Curr. Issues Pharm. Med. Sci.2016,29(4),184-189.

[29] B. Hiremath, B.H. Mathada, and M. unjayaswam: Development and validation of spectrophotometric methods for determination of ceftazidime in pharmaceutical dosage forms, Acta Pharm.,2008,58, 275-285.

[30] A.A.Jawad and K.H.Kathem: spectrophotometric determination of metoclopramide hydrochloride in bulk and pharmaceutical preparations by diazotization-coupling reaction, Inter.J.of Pharmacy and Pharmaceutical Sciences,2013.5(3),294-298.

[31] M. I. H. Helaleh, E. S.M. Abu-Namch, and R. M. A. Q. Jamhour: Direct titration and indirect spectrophotometric determination of selected cephalosporins, acta poloniae pharmaceutica,1998,55(2),93-97. 
[32] A. A. Ramadan, H. Mandil, and M. Dahhan: UV-VIS Spectrophotometric study for determination of cefixime in pure form and in pharmaceuticals through complexation with $\mathrm{Cu}(\mathrm{II})$ using acetate- $\mathrm{NaOH}$ buffer in water: methanol, International $J$. of Pharmacy and Phar. Sci.,2013,5(1),428-433.

[33] D. Harvey, (2000), Modern Analytical Chemistry, Mc Graw-Hill Higher Edu. USA, 2000,116.

Table 1. Formulation vials studied for Ceftriaxone sodium

\begin{tabular}{|c|c|c|}
\hline $\begin{array}{c}\text { formulationials } \\
\text { samples }\end{array}$ & Declared composition & Company \\
\hline $\begin{array}{c}\text { Ceftriaxone sodium } \\
\text { (Philtriaxone) }\end{array}$ & $1 \mathrm{~g}$ ceftriaxone sodium & $\begin{array}{c}\text { Binh duong company, } \\
\text { Vietnam }\end{array}$ \\
\hline $\begin{array}{c}\text { Ceftriaxone sodium } \\
\text { Per vial }\end{array}$ & $\begin{array}{c}\text { Sanaita,Pharmaceutical } \\
\text { GMBH company } \\
\text { (Werne Germany) }\end{array}$ \\
\hline $\begin{array}{c}\text { Ceftriaxone sodium } \\
\text { (Roth) }\end{array}$ & $1 \mathrm{~g}$ ceftriaxone sodium & $\begin{array}{c}\text { Pharma Roth Gmbh } \\
\text { company (Germany) }\end{array}$ \\
\hline $\begin{array}{c}\text { Ceftriaxone sodium } \\
\text { (Enoxirt) }\end{array}$ & $\begin{array}{c}\text { Per vial } \\
\text { (Englium }\end{array}$ & $\begin{array}{c}\text { Gulf Pharmaceutical } \\
\text { industries (UAE) }\end{array}$ \\
\hline $\begin{array}{c}\text { Ceftriaxone sodium } \\
\text { (Rameceftrix) }\end{array}$ & $1 \mathrm{~g}$ ceftriaxone sodium & $\begin{array}{c}\text { Tenth of Ramadan for } \\
\text { pharm.industries } \\
\text { company (Egypt) }\end{array}$ \\
\hline
\end{tabular}

Table 2. Influence of volume of DEAB reagent adding $\mathrm{ml}$ in color complex formed

\begin{tabular}{|c|c|}
\hline $\begin{array}{c}\text { (DEAB) reagent solution adding (ml) Volume } \\
\text { of }\end{array}$ & Absorbance \\
\hline 1 & 0.665 \\
\hline 2 & 0.701 \\
\hline 3 & 0.621 \\
\hline 4 & 0.587 \\
\hline 5 & 0.532 \\
\hline 6 & 0.463 \\
\hline
\end{tabular}

Table 3. Order of mixing the reagents influence

\begin{tabular}{|c|c|c|}
\hline No. & mixing order & Abs. \\
\hline $\mathbf{1}$ & $\mathrm{D}+\mathrm{R}+\mathrm{M}+\mathrm{A}$ & 0.720 \\
\hline $\mathbf{2}$ & $\mathrm{R}+\mathrm{M}+\mathrm{D}+\mathrm{A}$ & 0.615 \\
\hline $\mathbf{3}$ & $\mathrm{M}+\mathrm{D}+\mathrm{R}+\mathrm{A}$ & 0,510 \\
\hline $\mathbf{4}$ & $\mathrm{A}+\mathrm{D}+\mathrm{M}+\mathrm{R}$ & 0.471 \\
\hline $\mathbf{5}$ & $\mathrm{D}+\mathrm{M}+\mathrm{R}+\mathrm{A}$ & 0.533 \\
\hline
\end{tabular}


Table 4. Optimization of heating time and temperature on absorbance of color product

\begin{tabular}{|c|c|c|c|c|c|c|}
\hline $\mathrm{T}(\min )$ & $\mathrm{Abs}\left(25^{\circ} \mathrm{C}\right)$ & $\mathrm{Abs}\left(40^{\circ} \mathrm{C}\right)$ & $\mathrm{Abs}\left(50^{\circ} \mathrm{C}\right)$ & $\mathrm{Abs}\left(60^{\circ} \mathrm{C}\right)$ & $\mathrm{Abs}\left(70^{\circ} \mathrm{C}\right)$ & $\mathrm{Abs}\left(80^{\circ} \mathrm{C}\right)$ \\
\hline 5 & 0.083 & 0.211 & 0.241 & 0.233 & 0.159 & 0.112 \\
\hline 10 & 0.121 & 0.258 & 0.298 & 0.331 & 0.236 & 0.166 \\
\hline 15 & 0.156 & 0.299 & 0.351 & 0.387 & 0.289 & 0.213 \\
\hline 20 & 0.185 & 0.323 & 0.398 & 0.453 & 0.333 & 0.254 \\
\hline 25 & 0.209 & 0.474 & 0.465 & 0.501 & 0.377 & 0.271 \\
\hline 30 & 0.231 & 0.512 & 0.562 & 0.579 & 0.411 & 0.313 \\
\hline 35 & 0.288 & 0.598 & 0.632 & 0.607 & 0.421 & 0.334 \\
\hline 40 & 0.331 & 0.625 & 0.711 & 0.641 & 0.443 & 0.351 \\
\hline 45 & 0.331 & 0.627 & 0.710 & 0.639 & 0.441 & 0.350 \\
\hline 50 & 0.331 & 0.626 & 0.709 & 0.640 & 0.443 & 0.344 \\
\hline 55 & 0.330 & 0.626 & 0.711 & 0.638 & 0.439 & 0.326 \\
\hline 60 & 0.332 & 0.625 & 0.710 & 0.640 & 0.433 & 0.316 \\
\hline 65 & 0.331 & 0.627 & 0.711 & 0.636 & 0.423 & 0.305 \\
\hline 70 & 0.330 & 0.626 & 0.710 & 0.634 & 0.401 & 0.288 \\
\hline 75 & 0.331 & 0.628 & 0.709 & 0.634 & 0.389 & 0.267 \\
\hline 80 & 0.331 & 0.627 & 0.711 & 0.635 & 0.378 & 0.251 \\
\hline
\end{tabular}

Table 5. Shows the effect solvent on $\left(\lambda_{\max }\right)$ and absorbance for the color complex

\begin{tabular}{|c|c|c|}
\hline Solvent & $\boldsymbol{\lambda}_{\max }, \mathbf{n m}$ & Absorbance \\
& & \\
\hline Ethanol & 468 & 0.571 \\
\hline Methanol & 432 & 0.421 \\
\hline 2- propanol & 398 & 0.221 \\
\hline 1-butanol & 366 & 0.310 \\
\hline Acetone & 400 & 0.128 \\
\hline Chloroform & 350 & 0.088 \\
\hline Dimethyl sulphoxide & 362 & 0.131 \\
\hline Dimethyl formamide & 380 & 0.211 \\
\hline CCl & 330 & 0.013 \\
\hline Benzene & 346 & 0.140 \\
\hline nitrobenzene & 336 & 0.102 \\
\hline Teri butyl alcohol & 390 & 0.344 \\
\hline Formic acid & 352 & 0.186 \\
\hline Di ethyl ether & 344 & 0.211 \\
\hline Water & 496 & 0.711 \\
\hline
\end{tabular}


Table 6. Optical analytical characteristics and Precision for the studied method

\begin{tabular}{|c|c|}
\hline Optical analytical characteristics & Values \\
\hline$\lambda \max (\mathrm{nm})$ & 496 \\
\hline Molar absorptivity $\left(\right.$ lit. $\left.\mathrm{mol}^{-1} \cdot \mathrm{cm}^{-1}\right)$ & $2.1184 \times 10^{4}$ \\
\hline Beer's Law limits $\left(\mu \mathrm{g} / \mathrm{ml}^{-1}(\mathrm{x})\right.$ & $2-52$ \\
\hline Sandell's sensitivity $\mu \mathrm{g} / \mathrm{cm}^{2}$ & $4.8 \times 10^{-5} \mathrm{~g} . \mathrm{cm}^{-2}$ \\
\hline$\left(\right.$ LOD) Limit of detection $\left(\mu \mathrm{g} \cdot \mathrm{ml}^{-1}\right)$ & 0.421 \\
\hline$\left(\right.$ LOQ) Limit of quantification $\left(\mu \mathrm{g} \cdot \mathrm{ml}^{-1}\right)$ & 1.121 \\
\hline Regression equation $(\mathrm{y}=\mathrm{bx}+\mathrm{a})^{*}$ & $\mathrm{y}=0.032 \mathrm{x}+0.0484$ \\
\hline Slop $(\mathrm{b})$ & 0.032 \\
\hline Intercept $(\mathrm{a})$ & 0.0484 \\
\hline Correlation coefficients $(\mathrm{r})$ & 0.9992 \\
\hline RSD\% & 0.921 \\
\hline Recovery $\%$ & 99.970 \\
\hline Confidence limits with 0.05 level & \pm 0.0018 \\
\hline Confidence limits with 0.01 level & \pm 0.0027 \\
\hline
\end{tabular}

Table 7. Investegation of 20ppm CFT in the presence of excipients

\begin{tabular}{|c|c|c|}
\hline Interference & \% Error & \% Recovery \\
\hline Lactose & -1.160 & 98.840 \\
\hline Talc & -1.080 & 98.920 \\
\hline Starch & +1.120 & 101.120 \\
\hline Acacia & +1.230 & 101.230 \\
\hline Sucrose & -1.500 & 98.500 \\
\hline Glucose & -1.150 & 98.850 \\
\hline magnesium stearate & +1.400 & 101.400 \\
\hline Tween 80 & -1.010 & 98.990 \\
\hline benzoic acid & -1.150 & 98.850 \\
\hline Aspartate & -1.230 & 98.770 \\
\hline microcrystalline cellulose & -0.100 & 99.900 \\
\hline PVP & +1.070 & 101.070 \\
\hline
\end{tabular}


Table 8. The present method was applying for the assay of five samples and pure form for(CFT) drug

\begin{tabular}{|c|c|c|c|c|}
\hline $\begin{array}{c}\text { Procedure } \\
\text { Applied }\end{array}$ & $\begin{array}{c}\text { Pharmaceutical } \\
\text { Formulation of } \\
\text { (CFT) }\end{array}$ & Recovery\% & $\begin{array}{c}\text { \%E Relative } \\
\text { Standard error }\end{array}$ & $\begin{array}{c}\text { Relative } \\
\text { Standard } \\
\text { Deviation \% }\end{array}$ \\
\hline \multirow{7}{*}{ Proposed method } & $\begin{array}{c}\text { PureURE } \\
\text { Ceftriaxone } \\
\text { sodium }\end{array}$ & 99.370 & -0.630 & 0.921 \\
\cline { 2 - 5 } & $\begin{array}{c}\text { Ceftriaxone } \\
\text { sodium } \\
\text { (Philtriaxone) }\end{array}$ & 99.100 & -0.900 & 0.882 \\
\cline { 2 - 5 } & $\begin{array}{c}\text { Ceftriaxone } \\
\text { sodium }\end{array}$ & 98.440 & -1.560 & 0.971 \\
\cline { 2 - 5 } & $\begin{array}{c}\text { Ceftriaxone } \\
\text { sodium } \\
\text { (Roth) }\end{array}$ & 100.830 & +0.830 & 0.7717 \\
\cline { 2 - 5 } & $\begin{array}{c}\text { Ceftriaxone } \\
\text { sodium } \\
\text { (Enoxirt) }\end{array}$ & 98.510 & -1.490 & 0.832 \\
\cline { 2 - 5 } & $\begin{array}{c}\text { Ceftriaxone } \\
\text { sodium } \\
\text { (Rameceftrix) }\end{array}$ & 101.090 & +1.090 & 0.921 \\
\hline
\end{tabular}

Table 9. the official method was applying for the assay of five samples and pure form for(CFT) drug

\begin{tabular}{|c|c|c|c|c|}
\hline $\begin{array}{l}\text { Procedure } \\
\text { Applied }\end{array}$ & $\begin{array}{c}\text { Pharmaceutical } \\
\text { Formulation of } \\
\text { (CFT) }\end{array}$ & Recovery\% & $\begin{array}{c}\text { \%E Relative } \\
\text { Standard error }\end{array}$ & $\begin{array}{c}\text { Relative } \\
\text { Standard } \\
\text { Deviation \% }\end{array}$ \\
\hline \multirow{6}{*}{$\begin{array}{c}\text { British } \\
\text { Pharmacopoeia } \\
\text { method [4] }\end{array}$} & $\begin{array}{l}\text { PureURE } \\
\text { Ceftriaxone } \\
\text { sodium }\end{array}$ & 99.130 & -0.870 & 1.122 \\
\hline & $\begin{array}{c}\text { Ceftriaxone } \\
\text { sodium } \\
\text { (Philtriaxone) }\end{array}$ & 101.230 & 1.230 & 0.911 \\
\hline & $\begin{array}{l}\text { Ceftriaxone } \\
\text { sodium }\end{array}$ & 98.140 & -1.860 & 0.982 \\
\hline & $\begin{array}{l}\text { Ceftriaxone } \\
\text { sodium } \\
\text { (Roth) }\end{array}$ & 98.200 & -1.800 & 1.077 \\
\hline & $\begin{array}{l}\text { Ceftriaxone } \\
\text { sodium } \\
\text { (Enoxirt) }\end{array}$ & 98.670 & -1.330 & 1.032 \\
\hline & $\begin{array}{c}\text { Ceftriaxone } \\
\text { sodium } \\
\text { (Rameceftrix) }\end{array}$ & 98.890 & -1.110 & 0.944 \\
\hline
\end{tabular}




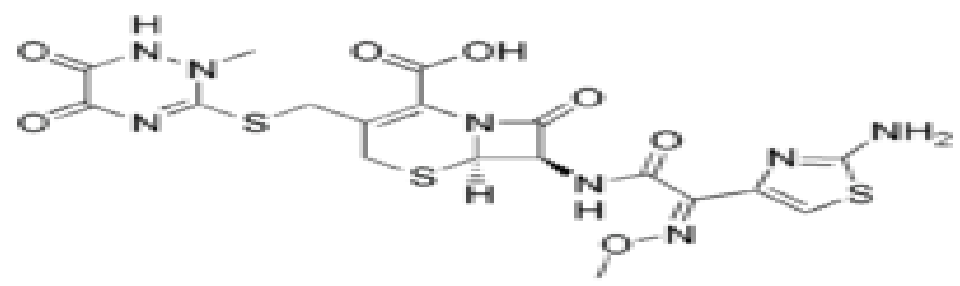

Figure 1. The chemical structures of Ceftriaxone drug

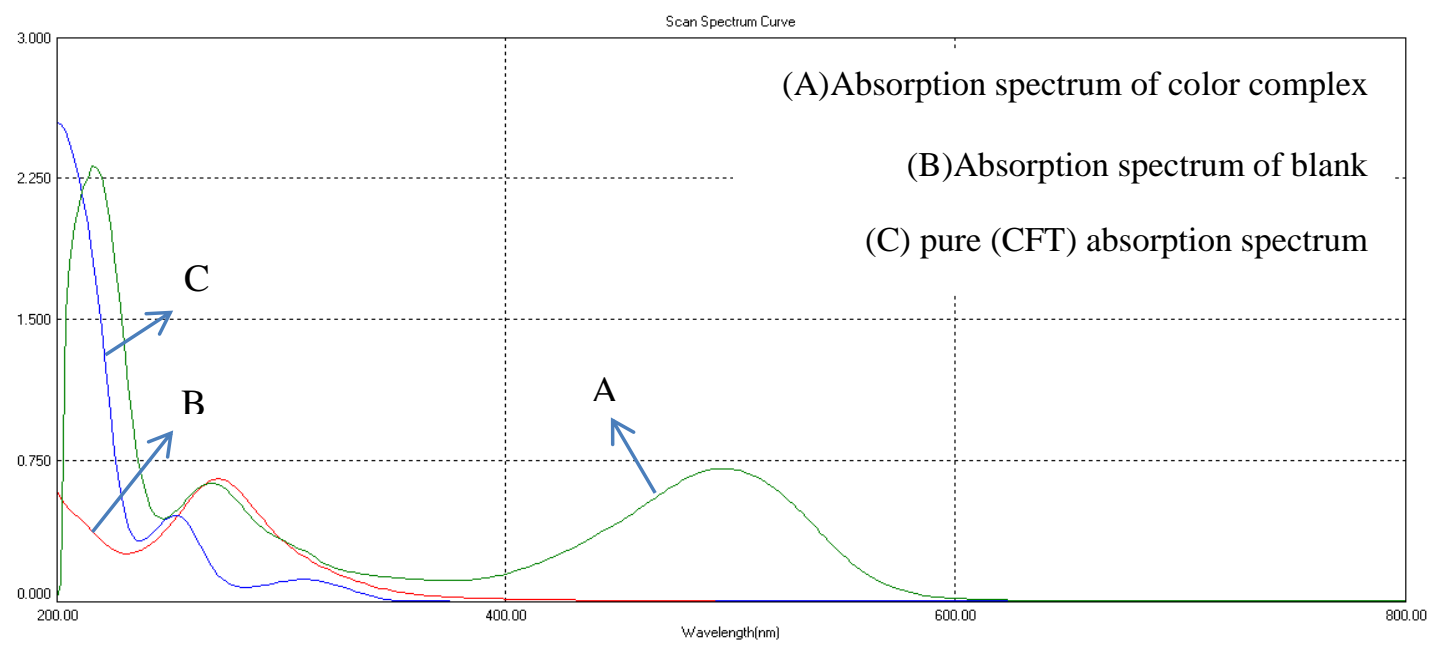

Figure 2. (A) absorption spectrum of color complex formed by(CFT) (20mg/ml), (DEAB) and cobalt ion solution in acidic media, (B) absorption spectrum of (DEAB) and cobalt ion solution in acidic media, $(\mathrm{C})$ pure (CFT) absorption spectrum

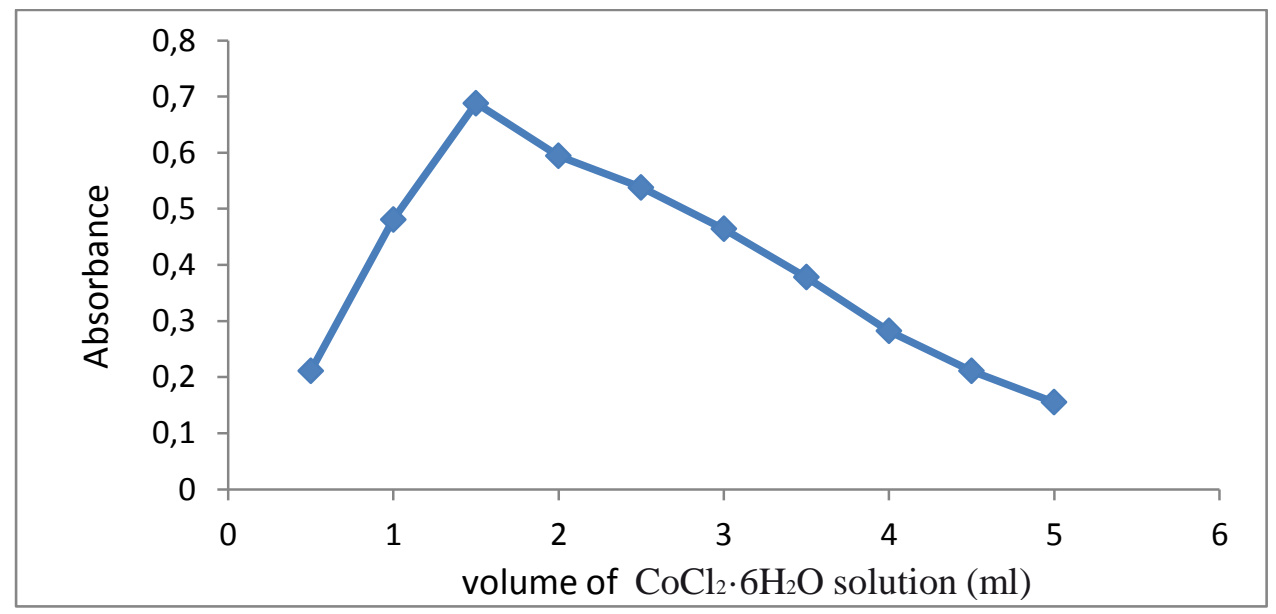

Figure 3. Cobalt chloride concentration influence 


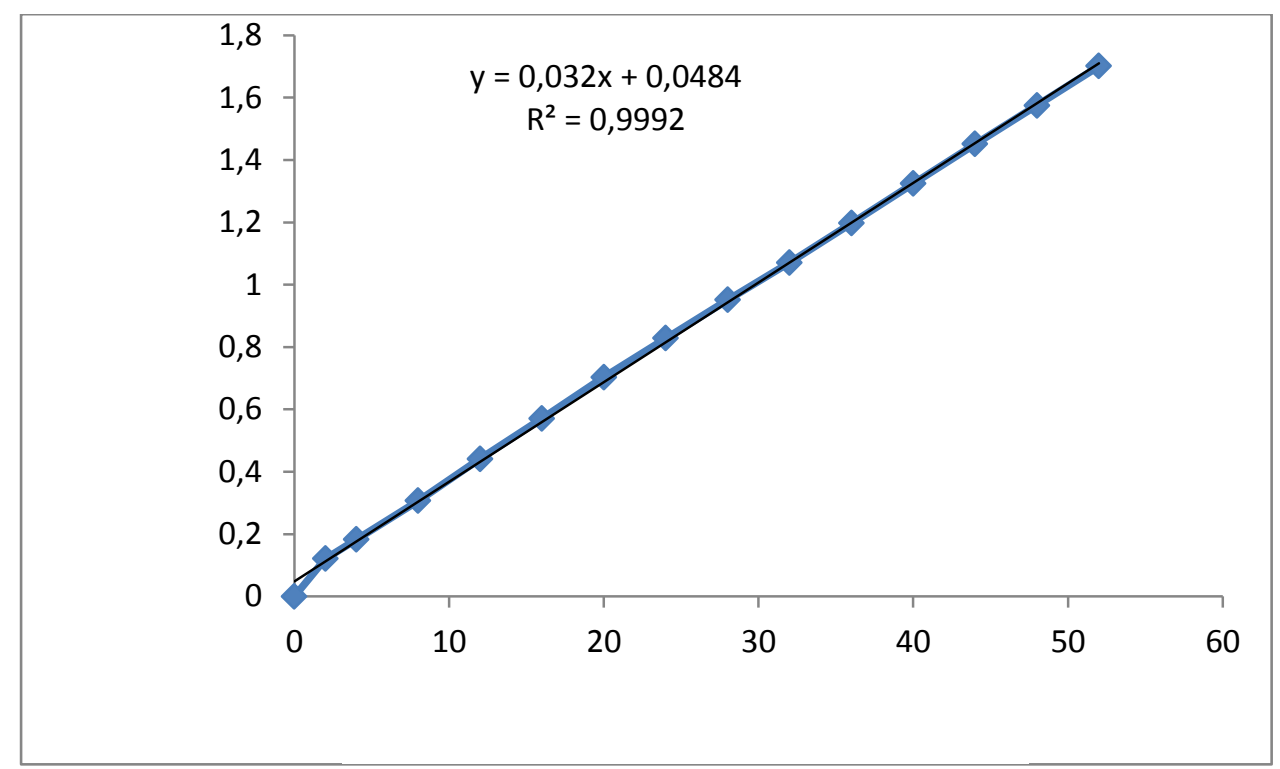

Figure 4. The calibration graph of (CFT) 